\title{
articles THE DISSEMINATION Of SCIENCE AND SCIENCE JOURNALISM IN BRAZILIAN UNIVERSITIES: analyzing strategies that facilitate access to Science $\&$ Technology
}

Copyright $@ 2016$ SBPjor / Associação Brasileira de Pesquisadores em Jornalismo
GIULIANA BATISTA RODRIGUES DE QUEIROZ

Universidade Federal da Paraíba, Brazil

VALDECIR BECKER

Universidade Federal da Paraíba, Brazil

\begin{abstract}
This article is a mapping of Brazilian universities that maintain a structured work for Science Journalism and / or the dissemination of science. It analyses the strategies used by the top 50 Brazilian universities for including dissemination of science in their communication activities. In order to do this each institution's website was examined for the purpose of collecting a large sample size of universities that organize and prioritize the dissemination of science and science journalism, and make their studies and projects available to the public. The dissemination of science is a priority for only 15 universities; ones that have structured science journalism programs. 11 of these universities are among the top 25 in the country which indicates that there is a direct relationship between academic quality and dissemination of science. Thus, this study lends to a deeper understanding of the field of science journalism.
\end{abstract}

Keywords: Dissemination of science; Science journalism; Institutional sites; Universities.

\section{JORNALISMO E DIVULGAÇÃO CIENTÍFICOS NAS UNIVERSIDADES BRASILEIRAS: análise de estratégias para facilitar o acesso à C\&T}

RESUMO - O presente artigo faz um mapeamento das universidades brasileiras que mantém um trabalho estruturado de Jornalismo Científico e/ou Divulgação Científica. São analisadas as estratégias das 50 melhores universidades brasileiras que inserem a divulgação científica nas demais atividades de comunicação institucional. Para tanto, foram analisados os sites destas instituições, gerando uma amostra significativa das universidades que adotam uma política de comunicação que organize e priorize aspectos da divulgação e jornalismo científicos, tornando públicas as pesquisas e os projetos desenvolvidos. Percebeu-se que a divulgação científica é uma preocupação apenas em 15 universidades, que mantêm setores de divulgação científica ou de jornalismo científico estruturados. Onze destas universidades estão entre as 25 melhores, o que permite concluir que há uma relação direta entre qualidade acadêmica e divulgação científica. Dessa forma, o presente trabalho contribui para um aprofundamento dos estudos na área do jornalismo científico.

Palavras-chave: Divulgação Científica; Jornalismo Científico; Sites institucionais; Universidades. 


\section{PERIODISMO E DIVULGACIÓN CIENTÍFICOS EM UNIVERSIDADES BRASILEÑAS: Análisis de las estrategias para facilitar el acceso a la C\&T}

RESUMEN - El presente artículo es un mapeo de las universidades brasileñas que mantienen un trabajo estructurado de Periodismo Científico y/o Divulgación Científica. Son analizadas las estrategias de las 50 mejores universidades brasileñas que insertan la divulgación científica en las demás actividades de comunicación institucional. Para ello, fueron analizados los sitios electrónicos de estas instituciones, generando una muestra significativa de las universidades que adoptan una política de comunicación que organice y priorice aspectos de la divulgación y periodismo científicos, tornando públicas las pesquisas y los proyectos desarrollados. Se percibió que la divulgación científica es una preocupación apenas en 15 universidades, que mantienen sectores de divulgación científica o de periodismo científico estructurados. Once de estas universidades están entre las 25 mejores, lo que permite concluir que existe una relación directa entre calidad académica y divulgación científica. De esta forma, el presente trabajo contribuye para un profundización de los estudios en el área de periodismo científico.

Palavras clave: Divulgación Científica; Periodismo Científico; Sitios Electrónicos institucionales; Universidades.

\section{Introduction}

Reporting on new scientific achievements is one of the key roles of the media. However, we have observed certain difficulties faced by professionals who work in newsrooms, especially when it comes to programming science journalism. These problems range from poor communication with the staff of the institutions doing the research to missing information on new findings and the low number of specialized professionals who focus on pressing issues and make them clear to the audience.

This difficulty in accessing information on science and technology (S\&T) is also observed in terms of ordinary citizens; the indirect funders of public research institutions and the ones who are (or at least should be) the final receiver of this information. Without proper mediation from newsrooms or any joint effort to ensure that knowledge produced in laboratories makes its way to the media, which society then ultimately uses, the scientific organizations will fail in making their S\&T information available to the public.

Even though the institutions that produce a large amount of scientific and technological knowledge and have teachers and researchers among their staff who are often interested in making their studies and analyses public, not all Higher Education Institutions 
(HEls) in Brazil are interested in creating agencies dedicated to facilitating access to the information they provide.

The purpose of this article is to analyze the dissemination of science from Brazilian universities to the general public in terms of giving this public access to scientific-technological production and, through the use of accessible journalistic language, providing access to information on available research and innovation. This is a way for ordinary citizens to obtain more knowledge even if it may appear superficial to experts within the field.

In this research, we found that among the 50 universities studied only 15 reserve specific platforms for scientific dissemination, and five of them stand out with good science journalism platforms. The other universities do not fail to address the issue; however, most of them have published news in the S\&T sector related to research as well as other issues of a general nature, not through media specifically designed for this purpose. We also realize that private universities are a minority among the top 50 and do not stand out in scientific communication, as they make up only a part of the list that maintains a platform for science communication.

A sample taken from the Folha University Ranking (RUF, 2015) shows how public and private universities in Brazil are positioning themselves and acting towards streamlining and democratizing the provision of communication services, especially in science journalism. In addition to presenting the operation modes of the institutions which provide a structured service of dissemination or science journalism, we will highlight five science journalism sites and how this type of service functions in public and private universities.

\section{Substantiation}

In recent decades, Brazil has been expanding and developing scientific and technological research in various fields, many with chances of being utilized by the national productive sector. It is interesting to note that most of this research comes from academic institutions and their respective university laboratories,

Scientific production in Brazil is concentrated in postgraduate courses and public universities. Of the 20 entities with the highest number of articles indexed between 1998 and 2002 , only three are not higher education institutions - the 
Oswaldo Cruz Foundation, the Brazilian Agricultural Research Corporation and the Brazilian Center for Physics Research. The others are state or federal universities. (SCHWARTZMAN, 2008, p.188)

This shows the historical relevance of these institutions. They are important not only in relation to education but also for the growth of the economy and the implementation of initiatives that promote the health and welfare of the nation's population, as well as other sectors.

A long process of communication needs to be established so that all of this scientific research content reaches ordinary citizens. It is more common for science dissemination to occur between institutions. It occurs among members of the academic community itself or between various educational institutions involved in research, extension and development. In this case, experts already have an outstanding knowledge of what is published and seek an exchange of information in journals, forums, associations and sites prepared for this purpose.

\footnotetext{
Researching is one of the basic purposes of the university, along with education and extending services to the community. What distinguishes a university from a single institution of higher education is precisely the space that it intended to develop the production of science and technology. (...) The implementation and growth of graduate courses were decisive factors for the advancement of scientific research. It is inevitable that their programs constitute the central point of this process, precisely because it is the teachers, researchers, scientists and professionals which are educated within them that Brazil can have now and in the future. (KUNSCH, 2008, p.27 and p. 31).
}

Given the importance of universities as major generators of Science and Technology, Kunsch (2008) advocates the need for disseminating research by reaching a large amount of people and using recognized communicative effectiveness, such as radio and television.

In order to be effective, scientific information is usually mediated by professionals from newsrooms or coordinators of communication from the institutions responsible for adapting the information and making it understandable to the general public. This is a key role and one of the final steps of scientific research. The "dissemination of results is a phase and not a part of the investigations with scientific content representing the highest expression of a researcher's social function" (TARGINO, 2007, p. 97). Science evolves and changes, which makes scientific research its main instrument and scientific communication its basic element. "The information is, ultimately, the basic input of scientific communication." (TARGINO, 2007, p. 97) 
The intention to inform is also a priority of most journalists working in S\&T. In a survey conducted by the Science and Development Network (SciDev.Net), 592 journalists working in S\&T were asked what they considered the main feature of their work to be. $43 \%$ of them saw their role as "informers", 23\% "to translate complex material," $13 \%$ "to educate", and less than 10\% saw their roles as entertainment or supervising the actions of public authorities (BAUER, 2013, p.24).

Thus, science should not be stagnant or an accumulation; it should be applied to daily life and contribute to the development of society. This is why science journalism should not be restricted to just particular readers or to those who have a particular affinity for the subject. The great challenge of science communication is to

attract the interest of new generations in schools, not only in order to make way for new vocations of research, but more importantly in order to make citizens well-informed and able to use the knowledge assimilated as an artifact of social change. (MELO, 2005, p. 61).

Providing society with more information and more critical thinking is one of the challenges that scientists face (and, in this particular case, the educational institutions that produce research) while trying to make scientific information available to the public.

\section{Internet as a facilitator of scientific communication}

Before looking at the scientific communication methods used by Brazilian universities, we need to define some basic concepts in this study in order to better understand the proposed objectives. First, we must understand what science dissemination is and what its relationship is with science journalism.

Science communication targets ordinary citizens (not experts in a particular area of S\&T) who at first might feel discouraged when it comes to complex technical terms or see them as a problem, yet, with minimum effort, would be able to understand the information in the related field. Dissemination is broader than science journalism because it is not dependent on science journalism and does not maintain a direct commitment to journalism; it can work with the audience across other forms of transmitting knowledge such as lectures, comic books, plays, classes, and more. For Wilson da Costa Bueno, "popular science achieves its primary function: to democratize 
access to scientific knowledge and to establish conditions for socalled scientific literacy" (BUENO, 2010)

According to Bueno (2010), science journalism would also be the "the process of diffusion of science and technology information by the media, that attains the attributes of journalistic production". It is most active in the press, which helps to circulate information about S\&T and at the same time acts as a mediator between the sources of information and the receiving audience. Scientific journalism would, therefore, be published and operated by professionals who understand the processes and common attributes of the profession such as contemporaneity, periodicity, commitment, quality of information, news dissemination, etc.

Sharon Dunwood (2014) believes that science journalism has been an increasingly necessary and important occupation since we live in a world where advertisers control the supply of information and citizens around the world are buffeted by a number of issues involving science and research. There are few places left to communicate independent, evidence-based information.

One way or another, the Internet has given our current society an easier way to gain access to scientific and technological knowledge, and now have the chance to see a popularization of a type of information that had long been restricted to experts and members of academic communities. Electronic communication has played a fundamental role in this interaction of scientists with their peers and science with ordinary citizens:

\footnotetext{
Science communication has a dual function; in addition to diffusing science, it makes a dialogue possible between scientists and society, seeking to create a feedback link to the construction of knowledge. Online Science Journalism and Science Communication can act as promising forms for making changes and how the society sees those changes. (PORTO, 2006, p. 278)
}

Thus, the internet gains emphasis among the electronic communication networks because it facilitates and streamlines the communication process, reaching those interested in particular subjects or fields of knowledge more efficiently. Journalists have adopted the Internet as a primary resource for research on stories, among other uses. Most people agree that it facilitates journalistic work and has opened lines of direct communication between audience members and between scientists and journalists (DUNWOOD, 2014, p.34-35). The Internet has also encouraged journalists in S\&T to become more entrepreneurial and 
seek new ways to explain important scientific developments to their audience. They have embraced social media such as Facebook and Twitter not only to connect with sources and their peers, but also to build their own personal brand (DUNWOOD, 2014, p.35-36).

In an assessment published by SciDev.Net, researchers also questioned journalists about the kind of media their reports used to appear in more often. Their answers were: printed media (90\%); stories on the web (Facebook 87\% - 75\%); followed by Twitter (56\%); and Blogs (54\%) (BAUER, 2013, p. 17). Other media such as radio, books and television, had lower positions which leads us to believe that resources made available on the internet reach a wider audience, as they currently provide greater publishing possibilities and are more likely to be viewed by readers.

Analysis of the research results below clearly shows that many universities, although facilitated by the Internet, do not hold science communication with much importance. On the contrary, they see it as being an unnecessary expense or an investment with no return.

In any case, contrary to this view, a portion of Brazilian universities have used their websites and portals on the Internet in order to ensure transmission of scientific and technological information to members of different cultures with varying degrees of comprehension and understanding. This does not mean they have stopped using the other communication platforms such as magazines, newspapers, radio and television programs, but in order to spread this kind of knowledge between different layers of population some include specific information channels in S\&T, since

\footnotetext{
The Internet, understood as a new combination media environment through a single channel, offers the possibility of an encounter between the receiver and various faces of communication, scattered across a number of specific supports. Contrary to the logic of a 'diaspora' communication, promoted by tight realities that may be appropriated from the printed, audio and video, the network enables the coexistence of all communication modes in the same space (DALMONTE, 2009, p.120).
}

Thus, educational institutions have a choice as to which platform they want to use on the Internet for broadening their reach and publishing their research and sharing the knowledge produced by scientists with the press and the public. The dissemination of science across the Internet is a viable form of encouraging dialogue between the public and the producers of S\&T, or among research institutions including the chance to promote society's interaction and participation in this process. 


\section{How Brazilian universities show scientific research}

For evaluating the performance of Brazilian universities with regards to science communication, we start with a selection of the 50 best Brazilian universities listed by the Folha University Ranking (RUF 2015). The research was carried out from their sites in order to answer the following questions: Does the institution conduct any outreach work in S\&T? If so, how? Is it done on the university's website or do they have some specific medium? Does the university offer multi-platform communication? If so, what are their actions?

The main objective of the research is to obtain a representative model of the institutions (whether public or private) that adopt a communication policy to organize and prioritize aspects of dissemination of knowledge and scientific journalism, making them public through its various communication platforms, projects and research developed in their labs, classrooms and/or extensions, in order to facilitate for the press and society in general to have knowledge about these outputs.

Historically, higher education institutions have played an important role in generating and disseminating research. Carvalho and Meneguelli (2006) showed that $32 \%$ of journalistic content in S\&T use universities as their main source. In second place were research institutes (20\%) that are usually related to or have close links with universities. Only $5 \%$ of the content is private companies as the source of information (CARVALHO AND MENEGUELLI, 2006, p.50).

Prominence for universities as sources of information on research has increased since the 1990s when a larger coverage took place in the newspapers for news production in scientific and technological areas (OLIVEIRA, 2010). Much of the information started becoming available through the institutional newsrooms which intermediated between the sources and the press.

\footnotetext{
The newsrooms in universities, research institutions and funding agencies for research were organized and started to produce newsletters, newspapers and magazines, which have made a considerable contribution to the country's major media outlets (OLIVEIRA, 2010, p.36).
}

Newsletters, newspapers and magazines were edited, printed and published by institutions and distributed among different audiences as the first, most viable option. Today, due to media convergence, there are different ways of focusing largely on the Internet using features 
such as interactivity, connectivity and multimedia (CAMPONEZ, 2002). Thus, traditional media focuses on a single support, giving the reader a number of options in a single medium.

These "new possibilities offered by technological development" (PEASANT, 2002, p.81) were observed in our study, when we noticed that the 50 analyzed universities were using informative institutional sites.

Only 15 of these same universities had reserved a specific platform for the communication of science, whether through science journalism or other forms of communication. There was an observable connection between the ranking and the communication of science across multiple platforms. Ten of the 15 top-ranked universities have specific platforms for science dissemination. However, it is surprising that three of them concern themselves with S\&T information yet are ranked below 40th.

Table 1 is a list of the RUF rankings, the names of the institutions, website addresses, which institutions publish science or practice journalism in S\&T and, finally, a brief description of their modes of action. The survey was taken between the months of October and November in 2015.

Table 1. Universities that promote science communication or science journalism (SJ)

\begin{tabular}{|c|c|c|c|c|}
\hline & INSTITUTION & SITE & $\begin{array}{c}\text { WHAT IS } \\
\text { PROMOTED? }\end{array}$ & MODES OF ACTION \\
\hline $1^{\text {st }}$ & $\begin{array}{c}\text { University } \\
\text { of São Paulo } \\
\text { (USP) }\end{array}$ & http://www5.usp.br/ & $\begin{array}{c}\text { Science } \\
\text { Journalism }\end{array}$ & $\begin{array}{l}\text { The site maintains an updated } \\
\text { "NEWS" topic and within it an } \\
\text { editorship of Science and } \\
\text { other technology (among } \\
\text { others). }\end{array}$ \\
\hline $5^{\text {th }}$ & $\begin{array}{c}\text { University } \\
\text { of Rio Grande } \\
\text { do Sul (UFRGS) }\end{array}$ & www.ufrgs.br & $\begin{array}{c}\text { Science } \\
\text { Journalism }\end{array}$ & $\begin{array}{l}\text { News about S\&T is more } \\
\text { concentrated in the "Park } \\
\text { News" section from the } \\
\text { Science and Technology Park } \\
\text { of UFRCS. It also has the } \\
\text { "Search Portal" specific to the } \\
\text { dissemination of research } \\
\text { and lists the knowledge } \\
\text { areas in alphabetical order. }\end{array}$ \\
\hline $6^{\text {th }}$ & $\begin{array}{c}\text { University } \\
\text { of Paulista } \\
\text { State Júlio de } \\
\text { Mesquita Filho } \\
\text { (UNESP) }\end{array}$ & www.unesp.br & $\begin{array}{c}\text { Science } \\
\text { Journalism }\end{array}$ & $\begin{array}{l}\text { Maintains an online magazine } \\
\text { and a printed version "Unesp } \\
\text { Science" and a Facebook } \\
\text { account specifically for } \\
\text { Journalism in S\&T produced } \\
\text { at the university. }\end{array}$ \\
\hline
\end{tabular}




\begin{tabular}{|c|c|c|c|c|}
\hline $7^{\text {th }}$ & $\begin{array}{l}\text { Federal } \\
\text { University } \\
\text { of Santa } \\
\text { Catarina } \\
\text { (UFSC) }\end{array}$ & www.ufsc.br & $\begin{array}{c}\text { Science } \\
\text { Journalism }\end{array}$ & $\begin{array}{l}\text { It has a specific area for } \mathrm{SJ} \text { on } \\
\text { the site and the newsletter } \\
\text { (by e-mail) discloses Science } \\
\text { with news about science } \\
\text { production. }\end{array}$ \\
\hline $8^{\text {th }}$ & $\begin{array}{c}\text { Federal } \\
\text { University } \\
\text { of Paraná } \\
\text { (UFPR) }\end{array}$ & www.ufpr.br & $\begin{array}{l}\text { Science } \\
\text { Journalism }\end{array}$ & $\begin{array}{l}\text { The site maintains the } \\
\text { editorship Science and } \\
\text { Technology and SACI offers } \\
\text { a platform to disseminate } \\
\text { academic research, extension } \\
\text { projects, events, etc. }\end{array}$ \\
\hline $9^{\text {th }}$ & $\begin{array}{c}\text { University } \\
\text { of Brasília } \\
\text { (UnB) }\end{array}$ & www.unb.br & $\begin{array}{l}\text { Science } \\
\text { Journalism }\end{array}$ & $\begin{array}{l}\text { Offers SJ through the UNB } \\
\text { Science site, schedules for } \\
\text { defending theses, and the } \\
\text { space "Post your research". } \\
\text { There is a registered } \\
\text { researcher's database. }\end{array}$ \\
\hline $10^{\text {th }}$ & $\begin{array}{c}\text { Federal } \\
\text { University } \\
\text { of } \\
\text { Pernambuco } \\
\text { (UFPE) }\end{array}$ & $\begin{array}{l}\text { https://www.ufpe.br/ } \\
\text { ufpenova/ }\end{array}$ & $\begin{array}{l}\text { Science } \\
\text { Journalism }\end{array}$ & $\begin{array}{l}\text { Sends a monthly newsletter } \\
\text { from the UFPE Research } \\
\text { Bulletin and maintains the } \\
\text { UFPE Health Connection } \\
\text { program at the University } \\
\text { FM Radio. }\end{array}$ \\
\hline $11^{\text {th }}$ & $\begin{array}{c}\text { Federal } \\
\text { University } \\
\text { of Ceará (UFC) }\end{array}$ & http://www.ufc.br/ & $\begin{array}{l}\text { Science } \\
\text { Journalism }\end{array}$ & $\begin{array}{l}\text { It has an interdisciplinary } \\
\text { physical space, "Seara } \\
\text { Science", for promoting } \\
\text { science and technology from } \\
\text { the UFC with laboratories, } \\
\text { exhibition halls, courses, } \\
\text { theatre, etc. and the site } \\
\text { searadaciencia.ufc.br. }\end{array}$ \\
\hline $12^{\text {th }}$ & $\begin{array}{c}\text { Federal } \\
\text { University } \\
\text { of São Carlos } \\
\text { (UFSCAR) }\end{array}$ & $\begin{array}{l}\text { http://www2.ufscar. } \\
\text { br/home/index.php }\end{array}$ & $\begin{array}{l}\text { Science } \\
\text { Journalism }\end{array}$ & $\begin{array}{l}\text { It has a printed and an } \\
\text { electronic journal of } \\
\text { science communication } \\
\text { "Univerciência" involving } \\
\text { scientists and communicators. } \\
\text { However, it seems that it has } \\
\text { not been updated since } 2003 \text {. }\end{array}$ \\
\hline $15^{\text {th }}$ & $\begin{array}{l}\text { Federal } \\
\text { University } \\
\text { of Bahia } \\
\text { (UFBA) }\end{array}$ & https://ufba.br/ & $\begin{array}{l}\text { Science } \\
\text { Journalism }\end{array}$ & $\begin{array}{l}\text { It has the News Agency in } \mathrm{S}, \mathrm{T} \\
\& \mathrm{I} \text {. An online vehicle produced } \\
\text { by journalists, students and } \\
\text { employees. Science and } \\
\text { Culture - news agency of } \\
\text { S\&T that offers spaces for } \\
\text { News, Interviews, Opinions, } \\
\text { S\&T Policies, WebTV, events } \\
\text { and researchers and Bank } \\
\text { researchers. }\end{array}$ \\
\hline $22^{\text {nd }}$ & $\begin{array}{c}\text { Federal } \\
\text { University } \\
\text { of São Paulo } \\
\text { (UNIFESP) }\end{array}$ & $\begin{array}{l}\text { http://www.unifesp. } \\
\text { br/ }\end{array}$ & $\begin{array}{c}\text { Science } \\
\text { Journalism }\end{array}$ & $\begin{array}{l}\text { It has a print magazine and } \\
\text { publishes popular science } \\
\text { works online in the editorials } \\
\text { Profile, Interview, Science } \\
\text { and Research in World } \\
\text { development. }\end{array}$ \\
\hline
\end{tabular}




\begin{tabular}{|c|c|c|c|c|}
\hline $36^{\text {th }}$ & $\begin{array}{l}\text { Federal } \\
\text { University } \\
\text { of Mato } \\
\text { Grosso do Sul } \\
\text { (UFMS) }\end{array}$ & http://www.ufms.br/ & $\begin{array}{l}\text { Science } \\
\text { Journalism }\end{array}$ & $\begin{array}{l}\text { Within the "newsroom" } \\
\text { there is a link to RESEARCH, } \\
\text { focusing on developed } \\
\text { science research at the } \\
\text { institution. }\end{array}$ \\
\hline $44^{\text {th }}$ & $\begin{array}{c}\text { Federal } \\
\text { University } \\
\text { of Rio Grande } \\
\text { (UFRS) }\end{array}$ & http://www.furg.br/ & $\begin{array}{c}\text { Science } \\
\text { Journalism }\end{array}$ & $\begin{array}{l}\text { It has the "Search Portal" } \\
\text { which provides information, } \\
\text { highlights, news and events } \\
\text { on science, technology and } \\
\text { available research. }\end{array}$ \\
\hline $45^{\text {th }}$ & $\begin{array}{l}\text { University } \\
\text { of Vale do } \\
\text { Rio dos Sinos } \\
\text { (UNISINOS) }\end{array}$ & $\begin{array}{l}\text { http://www.unisinos. } \\
\text { br/ }\end{array}$ & $\begin{array}{c}\text { Science } \\
\text { Communication }\end{array}$ & $\begin{array}{l}\text { Within the space "Research } \\
\text { and Innovation" there is a } \\
\text { dissemination of projects } \\
\text { and research that stands } \\
\text { out in Unisinos. The projects } \\
\text { applied in everyday life are } \\
\text { the link "Research in your } \\
\text { life." }\end{array}$ \\
\hline $46^{\text {th }}$ & $\begin{array}{l}\text { Technological } \\
\text { Federal } \\
\text { University } \\
\text { of Paraná } \\
\text { (UTFPR) }\end{array}$ & $\begin{array}{l}\text { http://www.utfpr. } \\
\text { edu.br/ }\end{array}$ & $\begin{array}{l}\text { Science } \\
\text { Journalism }\end{array}$ & $\begin{array}{l}\text { Linked to the Research and } \\
\text { Innovation sector there is } \\
\text { the Information Open Access } \\
\text { Portal (PIAA), an access tool } \\
\text { to the production of UTFPR } \\
\text { and specific journals in the } \\
\text { areas of S\&T. }\end{array}$ \\
\hline
\end{tabular}

The exclusion of some other universities from this table does not mean they do not exercise any form of scientific disclosure, it means that their materials in the areas of S\&T are just not concentrated in a specific space, but scattered across many themes, whether on the institution's website or on college radio and TV programs.

Although some universities did not meet the requirements of this list, they are worth mentioning here for the different modes of scientific communication they practice.

An example of a parallel work is the case of the Catholic University of Paraná (PUCPR), ranked at number 31 in the RUF in 2015. It did not create a specific platform for science communication but dedicated a section in the page "Research and Graduate education" (a list of links to all the institution's newspapers) facilitating the dissemination of science. It also maintains the "PUC Science" - a space in which to share works from PUCPR researchers in different fields of science (pucpr.br) with the scientific community and society.

The Federal University of Santa Maria - UFSM ( $18^{\text {th }}$ on the list) provides a link to the Educational Technology Center - NTE which aims to "democratize science knowledge to the different social strata" (ufsm.br). 
Another example is the Federal University of Uberlândia UFU ( $26^{\text {th }}$ in the RUF) that sustains parallel educational activities in an environment either through the Environmental Sustainability Board or through the ESEBA / UFU blog which promotes educational projects.

\section{Universities that value Science Journalism}

After identifying the fifteen institutions concerned with publishing their science research, we highlighted universities that stand out for having good platforms for science journalism. Keep in mind that this list does not follow any specific order handed down by the RUF 2015. This means that the overall quality of the institution often differs from the available platform it publishes its projects and research on.

We used the following criteria to analyze these examples: 1) Focus on science journalism and not science communication. 2) Simple and intuitive navigation without needing any technical knowledge to access and understand the reports. 3) Issues related to the areas of science and/or technology with an emphasis on knowledge generated in the institution. 4) Availability of updated news, at least once a week. 5) The target audience for the sections is the average reader, not the academic community.

The analysis showed five universities that excelled in all the criteria. It is worth noting that the five institutions are public ones and most of them provide tools/search and interactive platforms for the public, especially students and the press, which in turn facilitates consultations with researchers and/or specialty searches, or requests for researchers to register their research to serve as a theme for future contents.

UFBA ( $15^{\text {th }}$ in the RUF): The Federal University of Bahia provides access to an online newspaper with specific editorials (news, interviews with researchers, events, S, T\&I policies, opinion articles and lists of the most-read materials) at the following address: www.ascom.ufba.br and "Science and Culture Agency" (http://www.cienciaecultura.ufba.br/agenciadenoticias/). There is also a link to the Facebook page and WebTV. According to the agency's information page, its profiles on social networks - Twitter, Facebook and Flickr - aim to promote closer ties with the public and disseminate news about science.

It also makes a database of researchers available where you 
can search by name or area of expertise. The materials in S\&T are also signed by Journalism students and Agency trainees, which leads one to realize that the university promotes integration between teaching and practicing journalism.

The space also has a list of expert contributors in Scientific Journalism that, according to the site, is the first Bank of Researchers from Bahia directed to the Brazilian press.

UNESP ( $6^{\text {th }}$ place in the RUF): Paulista Julio de Mesquita Filho State University is possibly one of the most complete universities researched in this paper. It manages the online "Science Education" magazine www.unespciencia.com.br as well as a printed version. It is a good, clear, updated magazine with well divided subjects. Its servers save the current version of the magazine as well as older issues, but despite what the magazine's name implies, it merges science with other subjects such as Education, Music and Economics. The page itself offers the possibility of sharing issues on social networks and provides videos from the electronic magazine.

The UNESP magazine supports Science Journalism on its pages: "Its main objective is to focus on the knowledge generated in the institution" (unespciencia.com.br). It also has an interactive space for publishing comments.

UNB ( $9^{\text {th }}$ in the RUF): The University of Brasilia draws some attention with its "Our Researchers" tool, which provides access to the institution's researchers and data banks with more than one hundred experts available on the UNB portal: http://www.unbciencia. unb.br/. It has the option to search by name, department or subject and also lists each researcher's specialties.

The UnB site also provides a place where you can "Publish your Research", which instructs on "How to show your study at UnB Science" and the "Thesis Defense Schedule", which also happens to be a favorable space for the Department of Communication to monitor what the university's Science \& Technology program is producing. The site is interesting and divided into sections: Political Science, Researchers in the World, Books, Awards, What is it?, Collections, Laboratories, Museums and Scientists.

USP ( $1^{\text {st }}$ place in the RUF) - The University of São Paulo has a good website and has a specific editorial printed in the "USP News Agency" for 
Science and another one for Technology. The news is kept up-to-date and includes images of research as well as events and awards in these areas. Many materials show how these particular studies can affect life in Brazil and present it in an educational and straightforward manner.

UFPR ( $8^{\text {th }}$ in the RUF) - The Federal University of Paraná uses the Integrated Communication Support System (SACl), which is included on the institution's Social Communication Office (ACS) page -http://www.ufpr.br/portalufpr/mais-noticias-sobre-cienciae-tecnologia. The SACl allows teachers, coaches or students to disseminate research, extension projects, events, etc.

It offers the "Science and Technology" edition with a specific information area. The page is kept up-to-date and includes historical news as well as information about events in this area and teacher participation.

\section{S\&T in private vs. public universities}

Analyzing the list of 15 universities above, it is clear that Unisinos is the only private institution. In terms of the limited participation from private institutions in science communication or science journalism, Durham (1998) falls back on historical and economic information for justifying this limited participation. Since the 1960s there has been a remarkable increase in the number of private universities; however, due to the high cost of science research, private institutions made education the priority, leaving research on the backburner.

\footnotetext{
Private institutions on a whole did not institutionalize research. They depend on tuition fees for their funding, and since research is not a source of income, there is no interest in developing this activity or even in the ability to develop it. Moreover, the new National Education Law of Guidelines and Bases states that the criteria for an institution such as a university to be accredited does not require either higher university degrees or consolidated research activities (despite what is outlined in the Federal Constitution of 1988), thereby favoring a multiplicity of areas of knowledge.
}

Thus, the Brazilian university system differs when it comes to its private system for teaching and its public system which encourages research, even if it is not implemented in all institutions. Only recently has this reality begun to change. Private universities have started building research centers to acquire funding in order to compete with the public universities (DURHAM, 1998, p. 4 and 5).

Perhaps this explains why today, at the time of this analysis, few private universities have highlighted this area. However, if there 
is little research carried out in private universities in Brazil, one would expect those that do would publish more about it. Through our survey, we realized that this does not happen.

Out of the 50 institutions analyzed for this paper, only seven were run privately. This makes the fact that only one of the 15 universities in the communication table that exercises some form of science communication even more relevant. There is a silver lining here: even though the list is practically dominated by public universities, at least one of them is private; this is important.

\section{Discussion}

Studying Brazilian universities provided us with an important sample behavior of the communication procedures and science and technology research results being applied in the laboratories and classrooms of educational institutions, both public and private. In this regard, we found that the Internet serves as an excellent facilitator for science communication since all the universities analyzed in this paper have websites where they convey their news, including S\&T.

Dunwood (2014) explains that in many countries the traditional mediators or channels are standardized (such as TV) or are in decline, like newspapers. However the availability of the Internet as an information channel has profoundly affected the types of audience and demand for this type of information.

Also, before the Internet, it was very expensive to maintain structured science dissemination in traditional media, making it impossible formany universities to invest in. Since the onset of the Internet, transmission and printing costs have virtually disappeared. Production prices have been reduced significantly compared to analog media (Anderson, 2006).

This phenomenon is in line with the demand by Dunwood (2014): journalists prefer to search for information using digital media. However, it is crucial to note that only a small fraction of the universities analyzed in this study structures its extension services or science journalism on the Internet. In this respect, there is a gap between the demand for information from professionals and what the universities offer.

Unfortunately, the absence of these channels hinders the first contact of journalists, compromising the information objectives and educational approach discussed by Bauer (2013) as the search 
for information carried out by researchers is not as efficient as the filtering done in newsrooms.

Thus, the two most interested parties lose out in this reality: society remains ill-informed about scientific advances and the universities themselves lose recognition since they fail to communicate their findings. In addition, universities with high scientific reputations attract top students.

Traditionally, teaching, research and extension are considered to be responsibilities of Brazilian universities, but for many teachers and researchers, disseminating the results of academic work is not part of routine activities. Although Targino (2007) states that the dissemination of research results should be an integral step of the research process, it does not appear to be the case in most of the universities analyzed in this paper. In the eyes of the researcher or scientist, publishing the results at conferences or in journals appears to be enough. The absence of science journalism or science communication in structured platforms contributes to the fact that research results do not reach the ordinary citizen.

It isn't hard to imagine that Brazilian science could have a greater impact on society if it were properly communicated. Science and technology are not themes present in the everyday life for most of the country's population. Part of the responsibility of scientific illiteracy must be laid on researchers and institutions that do not fully play the role emphasized by Targino (2007) and Bueno (2010).

In addition, Dunwood (2014) warns of another problem that arises from the precariousness of science journalism: the commercialization of science. Businesses and advertisers produce misinformation as product sales strategies and this problem is accentuated with the lack of people and institutions doing research.

This author concludes that science communication is now more important than ever. It is a tool of social interest and accountability (Dunwood, 2014). In other words, science journalism should be a credibility locus to search for information related to research. As seen in this paper, this role is assumed by only a few institutions in Brazil.

Another point to consider is the fact that research in S\&T and the specific means of dissemination in the area are concentrated in the public higher educational system. Schwartzman (2008) explained this concentration on a historical perspective. Updating this analysis brought forth another hypothesis that helps explain the lack of attention that private universities give to research: the business model. Investing in science is expensive and is a high risk investment because the initial 
assumptions underlying the research can be refuted by the results. The Brazilian private educational scene nowadays is mainly concentrated into a few international conglomerates, and research and development are not assumed by the shareholders of these companies.

So, private institutions are likely to prioritize education, to the detriment of research and extension. This is a contradiction because private universities depend on their reputation among students in order to obtain higher enrollment. Therefore, one would expect greater disclosure to attract more students. In reality, this doesn't happen, which shows us that, on one hand, the private institutions do not see any social value in disclosure, and on the other, they believe that students do not hold their research with any regard.

It would be very important for disclosure in S\&T to receive adequate attention and be present in all universities. However, this study found that this does not happen, because in some cases the topic is given a professional treatment, but in most it is completely relegated to the background.

\section{Conclusion}

This article analyzed the dissemination of science from the 50 best universities in 2015 as ranked by the RUF. We observe that only 15 of them keep specific platforms for science dissemination and we identified five institutions (all public) that invest heavily in science journalism. The other universities treat the subject marginally, inserting news about research in sections with different themes. The private universities analyzed for this paper, with one exception, do not invest or invest little in science communication.

In view of these aspects, it is evident that there is a need to invest more in science communication and science journalism, especially to help reduce scientific illiteracy which is still prevalent in Brazil. Remember that Brazilian research, with a few exceptions, is funded by public money. This should increase the institutions and researchers' sense of responsibility for releasing the results to the public as a way of garnering more attention in journals and participation in congress.

This process could be enhanced by investing in digital media, especially the Internet. As discussed previously, journalists prefer digital platforms for collecting information which, besides being cheaper for universities, speeds up the publishing process 
and thereby provides the general public with more access to science information produced in the country.

Finally, it is worth highlighting that there is a potential for growth in areas of science dissemination and journalism in Brazilian universities. This research showed that there is a direct relationship between the dissemination of science information and the quality of education. Thus, the search for quality in the three main areas of activity in universities; teaching, research and extension, also involves the dissemination of research results. Furthermore, the five leading institutions identified in this study are good examples of creating good scientific journalism platforms. These are positive examples that should inspire other universities.

*This paper was translated by Rayssa Britto and revised by Fazal Hussain Chaudhry and by Lee Sharp

\section{REFERENCES}

ANDERSON, Chris. A cauda longa: do mercado de massa para o mercado de nicho. Rio de Janeiro: Elsevier, 2006.

BAUER, Martin W. ; HOWARD, Susan; ROMO Ramos, Yulye Jessica; MASSARANI, Luisa ; AMORIM, Luis. Global science journalism report: working conditions \& practices, professional ethos and future expectations. London, UK: LSE - The London School of Economics and Political Science, 2013. Available at: http://eprints.Ise.ac.uk/48051/1/ Bauer_Global_science_journalism_2013.pdf Access on: July 20, 2016.

BUENO, Wilson da Costa. Comunicação Científica e Divulgação Científica: aproximações e rupturas conceituais. Informação \& Informação, Londrina, v. 15, n. esp, p. 1 - 12, 2010. Available at: http://www.uel.br/revistas/uel/ index.php/informacao/article/viewFile/6585/6761 Access on: Nov. 07, 2015

CAMPONEZ, Carlos. Jornalismo de Proximidade: Rituais de comunicação na imprensa regional. Coimbra: Ed. Minerva Coimbra, 2002.

CARVALHO, Alessandra; MENECUELLI, Ana. A Ciência na imprensa Capixaba. In: SOUSA, Cidoval Morais de.; FERREIRA, Jose Roberto; BORTOLIERO, Simone (Eds.). Jornalismo Científico e Educação para as Ciências. Taubaté-SP: Cabral Editora e Livraria Universitária, 2006, p. 41-54. 
agenciadenoticias/quem-somos/ Access on: Oct. 10, 2015.

DALMONTE, Edson Fernando. Pensar o discurso no webjornalismo: temporalidade, paratexto e comunidades de experiência. Salvador: EDUFBA, 2009.

DUNWOODY, Sharon. Science Journalism - Prospects in the digital age. In: Routledge Handbook of Public Communication in Science and Technology - Second Edition. New York: Routledge Taylor \& Francis Group, p.27-39, 2014. Available at: https://books.google.com.br/books?hl=pt-BR\&lr=\&id=ArHcAw AAQBAJ\&oi=fnd\&pg=PA27\&dq=scientific + journalism\&,ots=2AkErnkUXB\&sig $=$ OaP3Qde5iG8AtU_wydRZujtjxC4\&redir_esc $=y \# v=$ onepage $\& q=$ scientific $\% 20$ journalism\&f=false Access on: July 17, 2016.

DURHAM, Eunice Ribeiro. As Universidades Públicas e a Pesquisa no Brasil. In. Reunião da Academia Brasileira de Ciências e Sociedade Brasileira para o Progresso da Ciência. Documento de trabalho. São Paulo: Núcleo de Pesquisas sobre Ensino Superior USP, 1998. Available at: http://nupps. usp.br/downloads/docs/dt9809.pdf Access on: Nov. 09, 2015.

KUNSCH, Margarida Maria Kroling. Universidade e Comunicação na Edificação da Sociedade. São Paulo: Edições Loyola, 1992.

KUNSCH, Margarida Maria Kroling. A pesquisa e a produção científica em comunicação no Brasil e sua integração com a sociedade. Comunicação, Ensino e Pesquisa / organização Sônia Virgínia Moreira e João Pedro Dias Vieira. Rio de Janeiro: EdUERJ, p. 27-50, 2008

MELO, José Marques de. Midiologia para iniciantes: uma viagem coloquial ao planeta mídia. Caxias do Sul (RS): Educs, 2005.

OLIVEIRA, Fabíola de. Jornalismo Científico. São Paulo: Ed. Contexto, 2010

pucpr.br . Puc Ciência. Available at: http://www.pucpr.br/pesquisacientifica/ diretoriapesquisa/pucciencia/index.php Access on: Oct. 10, 2015.

RUF.RankingUniversitárioFolha,2015.Availableat:http://ruf.folha.uol.com.br/2015/ Access on: Nov. 09, 2015.

SCHWARTZMAN, Simon (org.). Universidades e Desenvolvimento na América Latina - experiências exitosas de centros de pesquisa. Rio de Janeiro: Centro Edelstein de Pesquisas Sociais, 2008.

SOUSA, Cidoval Morais de. ; FERREIRA, Jose Roberto; BORTOLIERO, Simone (Eds.). Jornalismo Científico e Educação para as Ciências. TaubatéSP: Cabral Editora e Livraria Universitária, 2006, p. 148-156.

PORTO, Cristiane de Magalhães, et al. Jornalismo Científico e elaboração de banco de dados temático. In: SOUSA, Cidoval Morais de.; FERREIRA, Jose Roberto; BORTOLIERO, Simone (Eds.). Jornalismo Científico e Educação para as Ciências. Taubaté-SP: Cabral Editora e Livraria Universitária, 2006. 
TARGINO, Maria das Graças. O óbvio da informação científica: acesso e uso. TransInformação, Campinas, 9(2), p.95-105, May/Aug., 2007.

ufsm.br. NTE- Núcleo de Tecnologia Educacional. Available at: http:// site.ufsm.br/orgaos-suplementares/nte Access on: Oct. 10, 2015.

unespciencia.com.br. Quem somos novo . Available at: http://www. unespciencia.com.br/teste/ Access on: Oct. 10, 2015.

Giuliana Queiroz is a journalist and a Master's Degree student at the Postgraduate Program in Journalism at the Federal University of Paraíba (UFPB); Specialist in Journalism and Regional Media, she is currently a Journalist Communication Advisor, at the State University of Paraíba (UEPB).

Valdecir Becker is a journalist, Master of Engineering and Knowledge Management (2006 UFSC) and Doctor of Science (Electrical Engineering, 2011, USP). He is a Professor at the Science Computer Center and Postgraduate Program in Journalism at the Federal University of Paraíba (UFPB); researcher at LAViD (Digital Video and Applications Center); and member of the editorial board of the Brazilian Society of Television Engineering (SET). Over the years, he has participated in several academic projects related to Digital TV, studying new formats of convergent and multi-platform content and the impact of digital technologies in content and business models. He has written books and papers about digital TV, interactivity, $\mathrm{HCl}$, audience and reception studies. 